\title{
The Ethics of Farm Animal Biotechnology from an Anthropological Perspective
}

\author{
Philipp Aerni
}

check for updates

Citation: Aerni, P. The Ethics of Farm Animal Biotechnology from an Anthropological Perspective. Sustainability 2021, 13, 3674. https:// doi.org/10.3390/su13073674

Academic Editors: Gerhart U. Ryffel and Lewis Holloway

Received: 29 January 2021

Accepted: 19 March 2021

Published: 25 March 2021

Publisher's Note: MDPI stays neutral with regard to jurisdictional claims in published maps and institutional affiliations.

Copyright: (C) 2021 by the author. Licensee MDPI, Basel, Switzerland. This article is an open access article distributed under the terms and conditions of the Creative Commons Attribution (CC BY) license (https:/ / creativecommons.org/licenses/by/ $4.0 /)$.
Center for Corporate Responsibility and Sustainability (CCRS) at the University of Zurich, Zähringerstrasse 24, CH-8001 Zürich, Switzerland; Philipp.aerni@ccrs.uzh.ch; Tel.: +41-44-634-40-60

\begin{abstract}
Over the past 11,000 years, humans have domesticated a wide range of animals for different purposes designed to serve the human economy, society, and religious activities. The resulting mutual dependence between humans and their domestic partners created anthropogenic landscapes designed to sustain and protect their members. In this paper, we review the literature on the latest insights in interdisciplinary anthropological research on the evolution of animal domestication and breeding and put them in the context of the contemporary ethical debate on animal welfare and the application of modern biotechnology to animal breeding. Opponents of the use of animal biotechnology tend to see breeders often as enablers of industrial farming that would seek selective business advantage at the expense of the environment and animal welfare. Many applications of animal biotechnology may, however, also help to address environmental and animal welfare concerns in an effective way. Moreover, recent archeological and genetic research findings on the history of animal domestication reveal a distinctive kind of mutualism in the human-animal relationship based on a gradual co-evolutionary process with clear benefits for both parties in the relationship. These insights challenge the popular Neo-Darwinian account of unilateral adaptation only benefiting the more powerful party. Instead, they support the hypothesis that humans do not just adapt, but actively shape the environment through cultural niche construction (CNC) that also involves care and protection for domesticated animals. These empirical findings should also be taken into account in the contemporary ethical debate on animal welfare, which has become increasingly detached from the real-world efforts to improve animal welfare through best practices.
\end{abstract}

Keywords: animal domestication; animal welfare; anthropology; ethics; farm animal biotechnology

\section{Ethical Issues Related to Animal Biotechnology}

In 2015, the best-selling author Yuval Harari [1] published an article in the UK daily newspaper The Guardian titled "Industrial farming is one of the worst crimes in history". He argues that animal cruelty started with the agricultural revolution that led to the appearance of a completely new life-form on Earth: domesticated animals. The suffering of domesticated animals then worsened with the passing of generations.

He sees the root of the problem in the ignorance of farmers who would not be aware that domesticated animals have inherited many physical, emotional and social needs from their wild ancestors that remain unaddressed. In other words, domesticated animals in confinement live in an 'unnatural' state, which he believes is the source of all their suffering.

His views are partially derived from the seminal book Animal Liberation published in 1975 by the philosopher and utilitarian ethicist Peter Singer [2]. The book is widely considered to have contributed to the emergence of the animal protection movement as much as Rachel Carson's book Silent Spring, published in 1962, helped jump-start the environmental movement.

Singer stated that animals and humans share the capacity to suffer pain and that this capacity justifies equal consideration in our treatment of different species.

In the 1970s, animal suffering in industrial farming was not widely recognized. Animal products were not considered to be different from any other commercial products. After 
all, domesticated animals have been selectively bred in response to the need to increase the availability of animal products in an increasingly urban society that no longer produces its own food. That is the reason why farmed animals in the countryside exist in the first place. In this context, Singer convincingly argued, however, that once a sentient being exists, we have an obligation to avoid causing unnecessary suffering to this being.

Since then, many public and private standards have been passed across the world to prevent unnecessary suffering in animal production [3]. International guiding principles for animal protection were developed in 2008 by the World Organisation for Animal Health (OIE). The OIE counts 170 member states, which are expected to take them into account in national legislation. The OIE standards address specific welfare challenges, including the transport and slaughter of animals, production systems for cattle and poultry, the control of stray dog populations, and the use of animals in research. These standards are based on scientific evidence and the fundamental principles for animal welfare known as the 'five freedoms': freedom from hunger, thirst and malnutrition, from physical and thermal discomfort, from pain, injury and disease, from fear and distress, and to express normal patterns of behavior [4]. In addition, the OIE also publishes numerous specialized international standards that are directly or indirectly designed to improve animal welfare [5]. Moreover, a wide range of new technologies have been developed to implement the new requirements and sometimes even go beyond them [6].

Nevertheless, complying with strict standards of animal welfare requires additional means to be invested in welfare enhancing managing practices and technologies. Since the profit margins in the animal production industry are already quite narrow, there is a reluctance to adopt such measures unless governments are willing to actively support animal producers in their efforts to improve animal welfare by determining the optimum rather than maximum production levels [7]. Yet, many governments in low-income countries lack the means necessary to support transitions toward optimal levels of production that focus as much on animal welfare as on productivity [8]. As a consequence, quality animal products that stand for a good treatment of animals often remain niche premium products produced in high income countries but largely out of reach for poor consumers.

Large-scale improvements that could also improve animal welfare in low-income countries are therefore more likely to come from technological change designed to eliminate harmful practices, increase disease resistance, and promote sustainable intensification.

In this context, animal biotechnology may eventually make a substantial contribution [9]. For example, the use of modern biotechnology to render domesticated animals more resistant against disease in high- and low-income countries [10] may not just benefit the animal production system, but also contribute to a decrease in animal suffering [11]. Current research breakthroughs in modern animal biotechnology include resistance against mastitis [12] and pathogenic bacterial species, such as Staphylococcus aureus and Mycobacterium tuberculosis [13-15] in cattle, or resistance against the porcine reproductive and respiratory syndrome (PRRS), which causes huge losses and suffering in the pig industry [16]. Moreover, chickens resistant to avian influenza virus [17] or Atlantic salmon resistant to salmon lice [18] have the potential to massively reduce the use of environmentally harmful medications in the chicken and salmon industry, respectively.

Gene editing has also been successfully applied to produce hornless cows [19] or to ensure that pigs do not develop boar taint [20]. This allows the respective domesticated animals to avoid painful procedures such as dehorning and castration without losing any of the prior preferred characteristics. Gene editing may eventually also offer ways to eliminate other painful procedures such as tail-docking, debeaking, or branding. Moreover, gene-editing is one of the promising techniques applied to end the practice of male chicken culling in the chicken meat industry [21]. As a result, it could help avoid the killing of roughly 7 billion hatched male chickens per year worldwide [22].

Applying modern animal biotechnology in this context would largely comply with the so-called Principle for the Conservation of Welfare defined by the philosopher Bernard Rollin [23] to delimit the permission of applications of genetic engineering in animal 
breeding. It argues that genetically engineered animals should be no worse off, in terms of suffering, after the new traits are introduced into the genome than the parent stock was prior to the insertion of the new genetic material. Shriver [11] deduces from this principle that if we have an opportunity to prevent suffering or to avoid the creation of new suffering at little or no cost, and we fail to act on that opportunity, then we have done something wrong.

\section{The Contemporary Debate on Animal Domestication and Breeding}

The positive developments in the efforts to improve animal welfare through improved practices and new technologies have hardly been noticed in the controversial public debate on animal biotechnology. In fact, progress in the field of animal welfare in industrial farming seems almost like a contradiction to affluent consumers who assume that only premium organic meat, eggs, and dairy products may possibly be derived from animals who were not subject to unnecessary suffering.

This is not surprising in view of the frequent media coverage of animal abuse by individuals who see no obligation in avoiding unnecessary pain to the animals over which they have control. However, deliberate cruelty toward animals is treated as a crime in most OECD countries [24,25]. Switzerland protects animal dignity on the constitutional level, which has led to one of the strictest animal welfare regulations in Europe [26,27]. For example, the Swiss Federal Office of Agriculture has issued instructions on animal welfare requirements for geese in industrial farming that may be associated with 'wellness' rather than mere welfare [28]. They require farmers to ensure, among other things, that their geese have access to safe and easily accessible outdoor water bodies all day long and to supervise the geese entering the water body for the first six weeks to avoid any accidents. Such time-consuming and costly requirements may sometimes be counterproductive in the sense that they discourage domestic goose production and increase the share of imported geese from countries with much lower standards of animal protection [29].

At the international level, the animal welfare protection of different countries is monitored by the so-called Animal Protection Index (API). The index ranks countries based on their compliance with pre-defined animal welfare criteria [30]. The comparison tool allows regulation and policy approaches in different countries to be compared at a glance and provides a useful snapshot of the position in each country in each of the areas assessed by the API. Such initiatives may pressure laggards to embrace more comprehensive legal measures. However, merely passing a law while lacking the means to implement it does not change much. API reviews on animal protection measures do not just cover livestock producers but also other business-oriented activities in which animals are held in captivity (including animals used in scientific research, draught and recreation, and the breeding and sale of pets) as well as pet holders who keep animals as companions. In this context, the ability to control the treatment of pet holders and to hold them accountable in case of animal abuse is much more limited [31]. Therefore, animal cruelty is assumed to be more widespread among pet holders than among livestock holders [32,33].

\section{Animal Ethics without Anthromorphism}

Singer's book Animal Liberation [2] and the numerous emotion-driven campaigns for animal protection and animal rights deserve credit for having created the public awareness that was necessary to induce policy makers to pass legislation designed to reduce unnecessary animal suffering. However, it may have also led to a sort of ethical overshooting or hypermoralism, as it manifests itself in Critical Animal Studies (CAS), an increasingly popular subject in the humanities. CAS scholars have been criticized for their implicit misconceptions and anthropomorphism that are also partially found in Singer's original work [34].

However, is there an alternative in animal ethics one may consider of equal value and more in line with the realities in the practical world? The philosopher Baruch de Spinoza may be a candidate. Even though he lived three centuries before Singer, his 
approach to ethics has not lost any of its relevance and his description of human nature has been largely validated empirically by recent insights in neuroscience [35], experimental anthropology [36], and moral psychology [37].

Spinoza addressed animal rights concerns in Ethics, his most famous book [38]. Unlike his contemporary, Descartes, he did not regard animals merely as biological machines but understood them as sentient creatures that experience pleasure and pain [39]. One may therefore assume that Spinoza would have agreed with Singer's demand to assign equal consideration of the treatment of animals. However, Spinoza does not display much sympathy for this idea in the paragraph on the slaughtering of animals in part IV of Ethics [39]. According to Spinoza, the nature of animals is different from the one of humans insofar as humans can make use of reason to embark on collective action. It enables them to convert nature into culture thanks to a unique form of shared intentionality that was not observed in any other animal [36].

In their universal desire to remain in existence, humans depend on the care of as well as on the cooperation with other humans. Humans also care for their domesticated animals and a relationship of mutual affection may exist in many cases. Yet, even though it is reasonable to treat these animals in a way that does not cause unnecessary suffering, they have been domesticated for a particular purpose, namely, to supply animal-based resources. Accessing these resources may require the slaughtering of animals. In this context, Spinoza argues that making use of animal resources is justified because humans need to meet their needs as much as omnivore animals need to meet their needs in the wilderness. Therefore, he argues that "We have the same right against them that they would have against us" [38]. This indeed raises the question why we regard the killing of an animal by a human as morally problematic, but not so when an animal kills a human. It reveals a misconception that is related to the unquestioned anthropomorphism in Singer's term 'Speciesism' [2]. The term was used by Singer to point at our bias to merely care about the interests of those whom we consider belonging to our own species. However, from an anthropological point of view, humans had to limit their moral concerns to the human community on which their existence depended. That was also the realm in which they were able to assume responsibility in an effective way.

\section{The Term 'Speciesism' and Its Career in the Humanities}

Singer's claim that our moral responsibility should go far beyond our species [2] makes more sense in a more affluent, globalized, and interconnected world. However, there is an increasing gap between merely voicing moral concern (activism) and effectively acting upon it (action). Since the humanities feel more affinity to activism than action in view of their considerable detachment from the world of practice, it is not surprising that the term 'Speciesism' has made an impressive career in academic papers to the extent that it has been elevated to a 'psychology of speciesism' [40]. It extends the bias of humans toward the unequal treatment of animals to many other political subjects such as the protection of minorities in society, as well as race and gender issues [41]. It is assumed that the 'speciest' assigns moral worth based on perceived species membership (human, white, male). As such, the 'speciest' has become a political metaphor designed to stand in for the dominant political faction that justifies its domination over others by pointing at perceived essential differences.

There are, however, advocacy groups for racial or sexual equality who argue that such reasoning confuses real differences (economic inequality restricting access to essential human rights) with false ones (a nurtured culture of victimhood). As such, it may have negative material consequences, and could tempt us to abandon our responsibilities toward others as well as the natural world [42].

Nevertheless, the field of Critical Animal Studies (CAS) has popularized the abovementioned metaphors, analogies and psychological models in the humanities. It failed, however, to critically investigate its own anthropomorphic pre-conceptions related to speciesism [43]. 
Its metaphors have nevertheless been influential leading to a sort of 'medicalization' of the discourse on animal welfare, 'diagnosing' critics of the radical animal protection movement as 'pathological' in the sense that they would unconsciously be guided by the false belief of speciesism preventing them from accessing their 'natural' sentiments [44].

This resulting popularity of activism in academia may also indicate a powerful value transformation in postmaterialist societies in the 21st century $[45,46]$. Most views that were considered progressive or even subversive in the 1970s have become mainstream in society, and in academia in particular. This also led to a power shift, and, with it, to a new dominant and rather reactionary belief-system in society and academia that cannot be challenged without facing 'microaggressions' in the form of being accused of representing the former "dominant class" (associated with speciesism) with its alleged victim insensitivity [47].

\section{Global Humanitarianism Applied to Animal Welfare}

The normative nature of the debates on animal welfare and animal rights in academia and society has led to a growing climate of intolerance toward more differentiated views that point at potential inconvenient trade-offs between costly domestic animal welfare measures and a growing share of import of animal proteins from countries with minimal or no animal protection laws.

The growing climate of intolerance also suggests that there is just one way that is morally acceptable: Since animals have the right not to be treated as property by humans, we should stop raising animals as property that is subsequently turned into meat products [48]. A meat-free society is assumed to be possible because meat consumption would be merely a tradition that does not meet any essential human needs anymore in the sense that there are ways to replace animal proteins through plant-based resources [48]. Such a view does not take into account that raising animals and using them as a 'mobile' asset for various purposes has always been an essential part of what makes us human, and still today, numerous nomadic tribes, who actually represent increasingly vulnerable minorities, make a living from owning, raising, consuming, and selling cattle.

In this context, raising animals goes far beyond meat consumption and the implied default scenario that 'liberated' animals would be free from pain is misleading. Domesticated animals have become dependent on being managed by humans. As such, they are also a product of human culture and this explains why we care about them-not just because they serve a particular use. Our specific obligations toward animals therefore entail treating them with respect and ensuring their well-being, while they exist, by continuously minimizing unnecessary suffering, also when ending their lives [49]. However, the responsible treatment of animals in everyday life is hardly a concern in the theoretical discussions on animal rights in academia.

Due to the detachment of real-world challenges in animal welfare, the academic debate is primarily about radical political demands, such as the call to end meat consumption, for example. This call has gained in popularity especially among ordinary young people who have grown up in affluence and are increasingly concerned about climate change and animal welfare. They are aware that such demands will be ineffective if the legal enforcement is limited to the nation state. As a consequence, they unite worldwide via social media with individuals and organizations who share similar concerns. As global movements, they are then able to put pressure on governments and international organizations to respond to their radical demands [50].

This type of global humanitarianism applied to animal welfare emphasizes the importance of giving every organism equal consideration, respect and dignity, as the Swiss constitution does. It reflects a shift of norms and values in an affluent post-material society that greatly benefited from economic globalization, and in which cooperation within the immediate community to meet essential material needs is no longer required. As a consequence, the perceived moral obligation in such societies becomes more abstract and utopic. It is no more about loyalty and solidarity within the community into which one was been born by fate. Instead, what used to be the norms and values that enabled cooper- 
ation within the extended nuclear family and the community in which it thrives, is now increasingly applied to every living sentient being on the planet, with special consideration to the vulnerable minorities, endangered species, and animals in captivity [43].

However, such an extension of morality from community to sentient beings at large may however not lead to less suffering by humans and animals in this world, but rather to the release of more aggression as a consequence of moral radicalization. According to Gehlen [51], ignoring the pluralistic nature of ethics and imposing a single abstract and universal concept of morality on the real world would ultimately require the destruction of the existing real world that is presumed to be governed by inferior types of morality or no morality at all. Throughout history, such attempts proved to increase rather than decrease human suffering because these abstract ethical concepts ignore the biological roots of morality [52,53]. Fairness and reciprocity are built-in human instincts that are linked more to our emotions and our unconscious than to our ability to reason and make conscious decisions [54]. Unlike classical normative ethics with its classical branches (deontic, consequentialist, discursive), the field of anthropology takes these scientific insights into account in its reasoning about the origins and the genesis of ethical principles that guide human action $[37,55]$.

By developing an ethical approach that is based on the proper understanding of human nature, the anthropological approach to ethics is not normative [56]. It challenges the view that contemplating on how the world "ought to be" can be detached from a proper understanding on how the world actually "is". As such, it is very much in line with the ethics of Spinoza [38]. It questions the normative view that moral behavior is unrelated to the human pursuit of enlightened self-interest.

As such, the anthropological approach to ethics is more practical, humane, and more aligned with the recent science-based insights on animal domestication gathered from the various fields of evolutionary sciences, such as genetics, archeology, and the study of the Anthropocene [57-59].

\section{Animal Domestication in the Context of the Academic Debate on the Onset of the Anthropocene}

Nobel Prize winner Paul Crutzen coined the term 'Anthropocene' in 2000 [60] to suggest that humans have become a geopolitical force on their own to the extent that it merits the recognition of a new geopolitical epoch. He associated the start of this epoch with the onset of the Industrial Revolution in the 19th century considering its global footprint fueled by colonialism and the large-scale burning of coal. Other scholars even favored a later date arguing that the 'great acceleration' of the human imprint on the Earth System took place after World War II with the start of the atomic age and the steep rise of greenhouse gas emissions [61,62].

William Ruddiman, who coined the term 'early Anthropocene hypothesis', challenged the view that the co-called 'Anthropocene' started only with the industrial-consumer civilization $[63,64]$. Setting such a late date would fail to take into account prior humaninduced climate change about 5000-8000 years ago, caused by the massive expansion of agriculture and the conversion of forests into farmland. This earlier transformation of the earth system may have taken place over an extended and uneven period of time but was nevertheless incisive in global impact [65,66]. Finally, Smith and Zeder [67] argue that the onset of the Anthropocene may have even started earlier with the initial domestication of plants and animals 9000-11,000 years ago. They point at archeobiological remains of early domesticates unearthed in sites across the globe that fall into a narrow time span immediately following the Pleistocene-Holocene boundary (ca. 11,000-9000 B.P) [67]. These remains would represent a clear and compelling pedospheric record indicating that these areas of initial domestication set the stage for ever expanding regionally tailored agricultural economies that increasingly modified the biosphere over the past 10,000 years. As such, the Anthropocene would essentially coincide with the Holocene epoch. This would make more sense, if one looks for the causes rather than the effects of humaninduced environmental change [68]. Even though the Working Group on the Anthropocene 
tends to favor the post-war 'Great Acceleration' period as the onset of the anthropocene [69] due to its massive impact, there is still no general scientific consensus when exactly the Anthropocene started.

What has been observed, however, is that the advocates of the later dates often argue in a normative way. They implicitly denounce the post-war generation for having created a consumerist culture that disrespects the planetary boundaries and eventually causes global environmental collapse unless the human mentality shifts away from anthropocentric to a more biocentric view. Yuval Harari's account of the disastrous decision of humankind to embark on the domestication of nature in the Neolithic [1,70] and, with it, initiate the fatal age of the Anthropocene may also be strongly normative. However, his normative view is not shared by the scientific community that explores the beginnings of animal domestication by making use of the latest techniques and instruments in archeology and genetics to gain more detailed empirical insights [57-59].

\section{Recent Findings in Archeology and Genetics Question Popular "Prime-Mover" Accounts}

While previous research suggested a single 'core area' of domestication, the recent accumulation of genetic evidence and refinements in methods point increasingly towards multiple geographical origins. This also implies that there was no single 'prime mover' globally that caused humans to domesticate animals and become farmers [71-73]. Nevertheless, prime mover accounts that claim to have identified a main single cause continue to dominate the discourse on the causes and impact of the origins of agriculture, not least because they are compatible with the Standard Evolutionary Theory (SET) derived from Charles Darwin [57,59].

One popular 'prime mover' account argues that animal and plant domestication took place in response to external factors related to resource depletion, climate change and population growth [72]. Such 'stress-based' models often rely in their argumentation on so-called Human Behavioral Ecology (HBE) explanatory models, such as the Optimal Foraging Theory (OFT) [73]. They are based on the Neo-Darwinian view that human resource choices are guided by optimizing principles that would allow to make predictions under which external circumstances domestication of certain species and, with it, the development of agricultural economies is likely to take place [74-76].

Another popular prime-mover account identifies the roots of the Neolithic revolution in a fundamental change of human social behavior that is unleashed under conditions of relative plenty. In this context, the underlying structuralist models [57] are implicitly based on a Neo-Darwinian world view as well. They imply that once human communities were able to overcome resource scarcity, they started to embark on subjecting the natural environment for the sake of accumulating goods that increase their power over other communities. This would represent a shift of human mentality toward a desire to grow beyond essential needs [77]. This mentality would also be related to the innate human propensity for self-aggrandizement and greed [78]. Harari's presumed assumptions about the motivation of humankind to embark on subjecting the natural environment in the Neolithic $[1,70]$ very much reflect this prime-mover account.

Yet, both types of prime-mover accounts have been challenged by the recent findings in genetics and archeology on the evolution of animal domestication [57]. They revealed that animal domestication is a nonlinear process driven by exogenous as well as endogenous factors. The process may suddenly stop and reverse its course or go off in unexpected new directions with no clear or universal threshold that separates the wild from the domestic [79]. The process is highly dependent on biological and social contingencies that pushed and pulled animals and their human partners into domestic relationships, which is well documented in the history of pig domestication [80,81]. In this context, Zeder [58] identified three crucial pathways to domestication that led to different types of human-animal relationships with a different impact on the landscapes managed by humans: 
(1) The commensal pathway consists of animals that have been drawn into anthropogenic environments because they feed on refuse around human habitats or prey on other animals that thrive in such habitats. They include dogs, cats, and mice but also fowl and pigs that became important providers of essential resources. Such animals develop social and economic bonds with their human hosts, who began to derive tangible benefit from the association.

(2) The prey pathway of domestication started with humans hunting particular prey species to obtain their meat. Hunting strategies to increase the prey availability eventually turned into early forms of game management, and later herd management strategies. They included a multigenerational control over the animal's movement with humans increasingly taking care of animal feeding and reproduction. The most prominent examples of the prey pathway to domestication are cattle, goats, sheep and other types of livestock.

(3) The directed pathway represents a more deliberate and directed process of domestication. The target are animals that serve a particular human need but lack the key behavioral characteristics that usually pre-adapt certain species to domestication. Therefore, the domestication of these animals requires a more deliberate effort and advanced technical skills. Horses are an example of the directed pathway. Unlike domestic livestock, they were domesticated to help in hunting, to transport goods, and to provide a wide array of animal products (meat, milk, bones, hide, manure), designed to provide nourishment as well as base materials for tool manufacturing, clothing, shelter and fertilizer.

This distinctive kind of mutualism that characterizes all three pathways of domestication is not restricted to humans and domestic livestock but is also observed in non-human species as well. There is for example a domestic relationship between leaf cutter ants and fungi that also resulted in behavioral, physiological, and morphological changes in both partners [82], as they are observed in the process of animal domestication by humans.

In the case of humans there is, however, also an opportunistic element not observed in non-human species. It involves the ability to select partner species based on genetic variants, leaving one relationship in favor of another, as well as the conscious manipulation of the life history of the domesticated species to enhance the benefits for the domesticator [59]. In this context, humans stand out for their ability to invent new behaviors and pass them on to others $[83,84]$. These acts of domestication are linked to countless historical decisions by humans to modify their environment in a way that ensures a more predictable, steady and abundant supply of essential resources for themselves and their community of which they are part of and on which their survival depends. In this context, domesticated animals have also become part of human culture because they depend on human care, while humans depend on the resources they provide. In other words, domestic animals have become part of human communities, which also reflects the existence of mutual affection [85-87], even in the case of farmers that raise pigs on an industrial scale [88]. Neo-Darwinian as well as (post-)structuralist accounts of human evolution tend to ignore this aspect.

Recent findings in genetics and archeology have confirmed the development of mutualistic relationships at the core of domestication, combined with the uniquely human ability to spontaneously invent new behaviors and to pass them on to others [59]. This process of cultural transmission is a crucial element in human evolution understood as a continuous conversion of natural habitats into cultural habitats that are managed by human beings to different degrees, depending on the abundance or scarcity of available natural resources.

\section{Niche Construction Theory (NCT) and Its Relevance for the Ethical Debate on Animal Welfare}

The American evolutionary biologist Richard Lewontin [89] was one of the first who argued that organisms do not just put up and adapt to any given external environment but rather actively shape it by constructing niches and habitats that are conducive to their needs. His argument eventually gave rise to the so-called human niche construction theory. 
It diverges from standard evolutionary theory (SET) in the sense that it recognizes that the evolution of organisms is not just guided by natural selection, but, in fact, co-directed by the ability of organisms to create niches [90,91]. In other words, offspring inherit not only genes, but also a modified locally selective environment relative to genetic fitness. Since niche construction is based to a great extent on biological mutualism, it is not just an adaptive response to resource depression, but also contains an active component [59]. Further, it is better able to explain why domestication and agriculture may have different regional trajectories with domestication often taking place at a much earlier stage [85-90].

In this context, the Cultural Niche Construction (CNC) by humans is especially powerful because it can rely on the inheritance of cultural knowledge, which is then partially transformed and passed on through numerous forms of social transmission and economic exchange $[59,91]$. The use of new instruments and technologies in archeology and genetics enabled the creation of high-resolution regional-scale records that support the emerging CNC hypothesis and challenge the single-factor explanatory frameworks as represented by the prime-mover accounts [59]. After all, the ability of humans to cooperate through shared intentionality [36] and to modify behaviors and pass them on through cultural transmission make them the "ultimate niche constructors". This may also be what the philosopher Spinoza meant when he referred to the unique ability of humans to make use of reason [38]. As such, these empirical findings may again help enrich the ethical debate on animal welfare, since they challenge the popular view that animal domestication was a zero-sum game benefiting exclusively humans at the expense of domesticated animals. They also challenge the strictly normative orientation in the ethical debate and suggest a more naturalistic approach recognizing the impact of the extension of human cooperation on the evolution of moral thinking [34-37,92].

This cultural and economic expansion of human culture through trade and exchange since the emergence of early civilizations also shifted the perception of humans on the question of who deserves equal moral treatment. The extension of mutual dependence from the small nuclear family/community toward supra-regional networks of cooperation also led to a more inclusive understanding of moral thinking. In the age of globalization, $\mathrm{t}$ view that "we are all in the same boat" and therefore share the same fate moved from immediate kinship-based networks to life on this planet in general, and with it. This may help explain the popular contemporary demand for equal moral treatment of humans and sentient animals in general [93], as expressed by representatives of global humanitarianism. Consequently, global humanitarianism would not be possible without prior economic globalization. For early humans who made a living as hunters and gatherers, the idea of extending equal moral treatment toward humans beyond their kinship-based clan and as well as animals would not have made sense. This should not be interpreted as a sort of 'moral inferiority', but rather as a reflection of the different conditions in which life had to be mastered [93].

\section{From Early Domestication to Animal Biotechnology}

Empirical research on the domestication of animals suggests that prey species (cattle, pigs, goats, sheep) were domesticated before the emergence of agriculture [93]. In many cases it was a local shortage of supply that induced humans to engage in hunting strategies that increased prey availability. Over time, these game-management strategies became herd-management strategies because humans started to deliberately select animals with favorable traits for domestication [94]. After the end of the Younger Dryas climatic downturn (around 11,700 years B.P.), year-long human settlements with broad-spectrum subsistence economies were observed with animal and plant resources, drawn from a wide range of ecozones. These animals and plants already revealed various signs of domestication and reflected a first type of mutual relationship that increased the survival rate of the domesticator as well as the domesticates. It left a genetic imprint on both parties [59]. Through cultural transmission, more and more techniques became available to increase manageability, robustness, productivity and reproductive ability of the domesticated species, which 
eventually transformed in certain cases the prey pathway into a directed pathway of domestication that is more intensive and focused on the artificial selection for specific traits. The directed pathway eventually must have paved the way toward science-based breeding because it required a deep understanding of animal behavior and management as well as the use of more sophisticated breeding technologies. As such, modern animal biotechnology may be considered the latest sort of technique in animal breeding. Its impact on the well-being of domesticated animals needs to be critically assessed from a historical perspective on a case-by-case basis.

\section{Action Versus Activism in Efforts to Improve Animal Welfare}

The contemporary ethical discussion on animal welfare in Europe and North America shows, little interest so far in the recent empirical insights derived from anthropological research or the latest technological advances to improve animal welfare in industry $[7,95,96]$. Instead, the ethical demands advocated by the animal rights movement seem to become more radical the more affluent a society is and the stricter animal protection laws have become [97].

Some animal rights scholars criticize the underlying theoretical assumptions of existing animal welfare laws since they would be based on utilitarian welfarism and rights-based approaches to animal welfare while ignoring the potential of academic fields such as Critical Animal Studies (CAS) to improve the justness and effectiveness of animal law [98]. CAS largely draws on earlier post-structuralist models applied to gender, racial and class discrimination that look at shifting patterns of power and domination that would raise fundamental ethical questions that remain unaddressed in the classical schools of normative ethics. As mentioned earlier, the CAS approach to ethics is also linked to popular terms in the humanities such as 'speciesism', 'otherness' and 'intersectionality' referring to multiple forms of discrimination of individuals due to attribution of a sort of inferiority by the supposed 'dominant class' [99]. Applied to animal ethics, the approach is assumed to call for viable alternative paradigms that treat animals just like any other (intersectionally) marginalized communities [100].

This trend indicates that animal ethics tends to be largely debated within academic and legal circles that do not have any links anymore to the practical world and the downto-earth ethical challenges that the animal farming industry is facing [7]. Instead, they see a great potential in social movements that share a similar narrative of decline and believe that a better world is possible if only environmental, feminist, animal rights and human rights movements unite to bring about "a cultural shift in human identity away from an egoistic anthropocentrism (human-centered outlook) and toward a universal altruism (beyond a species-centered ethic)" [100].

In other words, there is a widespread belief in the humanities and the social sciences that activism of like-minded groups rather than collective action that reaches out to different stakeholders in society will bring about sustainable change [98]. However, change cannot just be wished into being. Instead, it requires institutions and technologies that make concrete changes possible in the first place [101,102]. Activism is, however, more convenient since it does not require any commitment to achieve a particular target through concrete action. Moreover, it is morally unassailable, for who would accuse someone of campaigning for a good cause [100]? These advantages have also induced many politicians and celebrities to join campaigns, or at least to express their support, for the good cause. This phenomenon was also identified in research on social psychology as 'virtue signaling'. It reveals the need to signal one's prosocial status to others [103-105].

\section{Discussion}

Recent discoveries in genetics and archeology challenge established views on the history of animal domestication. They indicate that humans did not just adapt unilaterally to external pressures or experience a shift in mentality that would have resulted in the human urge to grow beyond sustainable levels. Such prime mover hypotheses that claim to 
have identified a single cause rooted in external stress factors or a shift in human mentality expressed in a new social behavior are directly or indirectly linked to a Neo-Darwinian view of human evolution, relying on an account of competition between individuals rather than effective cooperation within human communities. In interdisciplinary anthropological research this view is increasingly abandoned in favor of Cultural Niche Construction (CNC) theory, which emphasizes the cooperative nature of humans in their efforts to convert natural spaces into cultural spaces. CNC is more in line with the latest discoveries in archeological sites that are of relevance to our understanding of animal domestication. It argues that human communities actively shaped and transformed the natural environment to improve the chances of survival of subsequent generations. In this context, the $\mathrm{CNC}$ and its emphasis on human cooperation and biological mutualism in the relationship between humans and domestic animals is in a better position to explain the Neolithic revolution, which increased the impact of humankind on the environment to an extent that it is considered to mark the beginning of the Anthropocene (early Anthropocene Hypothesis).

The animal protection movement was certainly an important driver in the improvement of animal welfare in industrial farming over the past three decades. However, its narrative continues to be guided by Neo-Darwinian baseline assumptions that regards the shift in mentality during the transition from hunter and gatherer societies to more sedentary agricultural societies as the prime mover of change to benefit humankind at the expense of animals and the natural environment at large.

Many animal welfare activists tend to disregard the cooperative nature of humans and the biological mutualism in human-animal relationships that shaped the history of animal domestication. Instead, they have embraced a more simple and mythical account about a powerful species (humans) that forced the less powerful species (animals) into submission without any consideration of the suffering this may have caused for the domesticated creatures. The bestseller Homo Sapiens by Yuval Harari [70] very much builds on this type of portrayal in his "brief history of mankind". It highlights the fact that simple perpetrator-victim accounts about our origins and how we arrived at the current age of globalization are more popular because they provide meaning, orientation and identity. The more science-based and complex descriptions of the evolution of humankind may still lack such a convincing narrative that would allow it to become more widely recognized in public.

The field of anthropology is nevertheless committed to provide a synthesis of recent empirical and experimental findings in genetics, archeology, neuroscience, and evolutionary psychology that may render science-based accounts more meaningful. For many anthropologists, the history of the evolution of humankind is also a history of social cooperation designed to convert nature into culturally managed landscapes. As such, the so-called Anthropocene must be understood as the outcome of this process on an aggregated level. In the culturally managed landscapes that characterize the onset of the early Anthropocene, human relationships with domesticated animals represent a sort of biological mutualism (they depend on human care and we depend on the resources they provide) combined with the uniquely human ability to spontaneously invent new behaviors and pass them on to others (cultural transmission). The mutual dependence has left a genetic imprint on both sides.

The modern animal farming industry may appear to be completely unrelated to this early period of animal domestication. But a closer look reveals how much it is still connected to earlier efforts to direct animal domestication in a way that helps to increase the quantity and quality of animal products and services. In this context, it is misleading to simply assume that the situation of animal welfare has worsened with the raise of industrial farming A certain disregard for animal welfare in the early stage of the intensification of livestock production should not imply that animal cruelty was the norm rather than the exception. After all, a neglect of animal care may also result in a loss of revenue (e.g., loss due to disease, lower quality of the animal product), which could hardly be in the interest of the livestock enterprise.). 
The growing public and academic concern about animal suffering in the 1970s led to more strict regulation designed to stop abusive practices, predominantly in high income countries. Even though there are still legal loopholes, and animal abuse scandals still happen in countries that praise themselves for being responsive to animal rights concerns, the animal welfare situation over the past three decades substantially improved in many ways thanks to pressure from retailers, an enhanced focus on meat quality (meat from stress-free animals), and new technologies designed to improve animal welfare.

In return, animal welfare in low-income countries is still precarious because of the lack of means to implement animal protection measures in the handling, transport and slaughtering of animals, but also because domesticated animals in the Global South still suffer from many untreated 'natural' tropical diseases. Advocacy groups that aim to improve animal welfare in an effective way need to take these empirical facts into account and stop looking down on the actors involved in industrial animal farming and the business with animal-derived products. A much more effective approach is to search for best practices in animal welfare and campaign for their widespread adoption.

Many animal welfare activists tend to lump modern animal biotechnology together with other advanced technologies used in industrial animal management, transportation and trade. However, animal biotechnology is a platform technology with a wide range of specific applications. This makes it hard to compare it with other advanced technologies used at different stages and for specific purposes in the animal farming industry. Moreover, applications of animal biotechnology are scale-neutral in the sense that they may not just benefit the business of animal farming in high income countries but also address certain animal welfare challenges in traditional pastoralist communities in low-income countries in a cost-effective way. Moreover, as illustrated in this paper to some extent, many recent minimally invasive genetic changes in certain domestic animals, enabled through advanced gene-editing techniques, have the potential to improve animal welfare on a large scale.

These positive developments are not meant to deny that there are real ethical challenges that need to be addressed in animal biotechnology. However, assessing the impact of this platform technology on animal welfare should be guided by Rollin's Principle of the Conservation of Animal Welfare, requiring no increase in suffering, after new traits have been introduced into the genome (compared to the parent stock). It should also be recognized that animal biotechnology may as well help increase the well-being of animals. Therefore, a proper balancing of the risks and benefits of a particular biotechnology-based intervention designed to address a particular trait in a particular animal should be regarded as a basis for an informed and responsible decision to approve or deny the application submitted.

However, the contemporary animal ethics debate in the humanities tends to move away from these real-world challenges because of its strictly normative orientation (e.g., 'stop killing animals'). It renders new empirical insights on animal welfare practices de-facto irrelevant.

Anthropology is one of the few disciplines that builds bridges between the natural sciences, the social sciences and the humanities. Therefore, its approach to animal ethics is also more informed by empirical findings, as has been illustrated in this contribution. It may help to provide a more constructive ethical orientation that is not just concerned with highly abstract ethical concepts that are not in line with the basic empirical insights on human nature, but also takes into account the long history of human-animal relationship and the resulting mutual dependence.

Experience over the past decade has shown that dogmatic ethical views in academia and the animal protection movement are not really compatible with the UN Sustainable Development Goals (UN SDGs) who still pursue a human-centered approach designed to balance the social, environmental and economic dimensions of sustainability epitomized in its slogan 'people, planet and prosperity'. This slogan does not just reflect the moral concerns in high income countries about animal welfare, but also the equally valid moral concerns in low-income countries related to widespread human poverty and the resulting exposure to hunger and starvation. Traditional pastoral communities in the marginal areas 
of many countries in the Global South may have little patience with demands from the Global North to stop eating meat.

The recent findings in anthropological research may help introduce a new type of ethics that is better informed about 'the cooperative human' [106], the distinct forms of mutualism found in the evolution of human-animal relationships and the importance of the historical and geographical context. As such, the emphasis of the anthropological perspective is more on the ethics of inclusiveness [101,102]. The demand for inclusive and sustainable growth is also one of the main pillars of the UN SDGs. If the remaining ten years to achieve the ambitious Agenda 2030 is really meant to become a 'decade of action', as the UN Secretary General Antonio Gutierres called it, then we may have to embrace this new ethical approach, because it is focused on effective outcomes in the world of practice.

Funding: This research received no external funding.

Institutional Review Board Statement: Not applicable.

Informed Consent Statement: Not applicable.

Acknowledgments: The author would like to thank Isabelle Schluep for her valuable feedback.

Conflicts of Interest: The author declares no conflict of interest.

\section{References}

1. Harari, Y. Industrial Farming is one of the Worst Crimes in History. The Guardian. 25 September 2015. Available online: https: //www.theguardian.com/books/2015/sep/25/industrial-farming-one-worst-crimes-history-ethical-question\#comments (accessed on 30 December 2020).

2. Singer, P. Animal Liberation; Random House: New York, NY, USA, 1975.

3. Velarde, A.; Dalmau, A. Animal welfare assessment at slaughter in Europe: Moving from inputs to outputs. Meat Sci. 2012, 92, 244-251. [CrossRef]

4. Available online: https://www.oie.int/animal-welfare/ (accessed on 29 January 2021).

5. Available online: https://www.oie.int/doc/ged/D3369.PDF (accessed on 29 January 2021).

6. Fourneris, C. Smart Arming: How Technology is Improving Animal Welfare and Efficiency in Agriculture. Available online: https: / / www.euronews.com/2020/03/23/precision-farming-targeting-resources-to-save-on-cost-and-benefit-animalwelfare (accessed on 23 March 2021).

7. Grandin, T. Animal welfare and society concerns finding the missing link. Meat Sci. 2014, 98, 461-469. [CrossRef] [PubMed]

8. Gobena, G.; Kumsa, D. Review on the Effect of Handling, Slaughtering Process and Transport on Welfare of Animals and Meat Quality in Ethiopia. Anim. Vet. Sci. 2020, 8, 84. [CrossRef]

9. OECD Conference on Gene-Editing in Agriculture. Available online: http://www.oecd.org/environment/genome-editingagriculture/ (accessed on 5 March 2021).

10. Janssen-Tapken, U. Developing Optimized Cattle Breeding Schemes Based on the Demands and Opportunities of Poor Livestock Keepers in Eastern Africa with a Special Focus on Trypanosomiasis. Ph.D. Thesis, ETH Zurich, Zürich, Switzerland, 2009.

11. Shriver, A. Prioritizing the protection of welfare in gene-edited livestock. Anim. Front. 2020, 10, 39-44. [CrossRef] [PubMed]

12. Islam, M.; Rony, S.A.; Rahman, M.B.; Cinar, M.U.; Villena, J.; Uddin, M.J.; Kitazawa, H. Improvement of Disease Resistance in Livestock: Application of Immunogenomics and CRISPR/Cas9 Technology. Animals 2020, 10, 2236. [CrossRef]

13. Chen, W.; Zhang, Y.; Yeo, W.S.; Bae, T.; Ji, Q. Rapid and efficient genome editing in Staphylococcus aureus by using an engineered CRISPR/Cas9 system. J. Am. Chem. Soc. 2017, 139, 3790-3795. [CrossRef]

14. Choudhary, E.; Sharma, R.; Kumar, Y.; Agarwal, N. Conditional silencing by CRISPRi reveals the role of DNA gyrase in formation of drug-tolerant persister population in Mycobacterium tuberculosis. Front. Cell. Infect. Microbiol. 2019, 9, 70. [CrossRef]

15. Wu, Z.; Wang, Y.; Zhang, Y.; Chen, W.; Wang, Y.; Ji, Q. Strategies for Developing CRISPR-Based Gene Editing Methods in Bacteria. Small Methods 2020, 4, 1900560. [CrossRef]

16. Burkard, C.; Lillico, S.G.; Reid, E.; Jackson, B.; Mileham, A.J.; Ait-Ali, T.; Whitelaw, C.B.A.; Archibald, A.L. Precision engineering for PRRSV resistance in pigs: Macrophages from genome edited pigs lacking CD163 SRCR5 domain are fully resistant to both PRRSV genotypes while maintaining biological function. PLoS Pathog. 2017, 13, e1006206. [CrossRef] [PubMed]

17. Lyall, J.; Irvine, R.M.; Sherman, A.; McKinley, T.J.; Núñez, A.; Purdie, A.; Tiley, L. Suppression of avian influenza transmission in genetically modified chickens. Science 2011, 331, 223-226. [CrossRef] [PubMed]

18. Wargelius, A. Application of genome editing in aquatic farm animals: Atlantic salmon. In Transgenic Research; Springer International Publishing: Berlin/Heidelberg, Germany, 2019; Volume 28, pp. 101-105.

19. Young, A.E.; Mansour, T.A.; McNabb, B.R.; Owen, J.R.; Trott, J.F.; Brown, C.T.; Van Eenennaam, A.L. Genomic and phenotypic analyses of six offspring of a genome-edited hornless bull. Nat. Biotechnol. 2020, 38, 225-232. [CrossRef] 
20. Squires, E.J.; Gray, M.A.; Lou, Y. Effect of mutations in porcine CYB5A and CYP17A1 on the metabolism of pregnenolone. J. Steroid Biochem. Mol. Biol. 2019, 195, 105469. [CrossRef]

21. Tizard, M.L.; Jenkins, K.A.; Cooper, C.A.; Woodcock, M.E.; Challagulla, A.; Doran, T.J. Potential benefits of gene editing for the future of poultry farming. In Transgenic Research; Springer International Publishing: Berlin/Heidelberg, Germany, 2019; Volume 28, pp. 87-92.

22. Vogel, G.; Vogel, G. 'Ethical' eggs could save day-old chicks from slaughter. Science 2019, 365, 627-628. [CrossRef]

23. Rollin, B. The Frankenstein Syndrome: Ethical and Social Issues in the Genetic Engineering of Animals; Cambridge University Press: Cambridge, UK, 1995.

24. Phillips, A.; Lockwood, R. Investigating \& Prosecuting Animal Abuse: A Guidebook on Safer Communities, Safer Families E Being an Effective Voice for Animal Victims; National District Attorneys Association: Alexandria, VA, USA, 2013.

25. FAO. Gateway to Animal Welfare. Available online: http://www.fao.org/ag/againfo/themes/animal-welfare/aw-resources/ standards-policies-and-strategies / en / ?no_cache=1 (accessed on 5 March 2021).

26. Camenzind, S. Dignity of creature: Beyond suffering and further. In The Ethics of Consumption; Röcklinsberg, H., Sandin, P., Eds.; Wageningen Academic Publishers: Wageningen, The Netherlands, 2013.

27. Misicka, S. Strict welfare Legislation Makes Switzerland one of the Better Places to have Fur, Fins or Feathers. Here's Why. Swissinfo 2020. 18 January 2020. Available online: https:/ / www.swissinfo.ch/eng/animal-welfare_how-well-are-swiss-animalsprotected-/45489148 (accessed on 27 January 2021).

28. Available online: https://www.blv.admin.ch/dam/blv/de/dokumente/tiere/nutztierhaltung/huehner/fachinformationenhuehner/fachinformation-schwimmgelegenheit-gaense-und-enten.pdf.download.pdf/gaense-und-enten-schwimmgelegenheitfachinfo-10-5-(1)-d.pdf (accessed on 29 January 2021).

29. Hardegger, A. Aufstand der Gänsebauern. NZZ. 5 November 2020. Available online: https://www.nzz.ch/schweiz/schweizaufstand-der-gaensebauer-ld.1584558 (accessed on 7 January 2021).

30. API. Available online: https:/ / api.worldanimalprotection.org/ (accessed on 29 January 2021).

31. Sollund, R. Expressions of speciesism: The effects of keeping companion animals on animal abuse, animal trafficking and species decline. Crime 2011, 55, 437-451. [CrossRef]

32. Rollin, B.E. "We Always Hurt the Things We Love"-Unnoticed Abuse of Companion Animals. Animals 2018, 8, 157. [CrossRef]

33. Newberry, M. Pets in danger: Exploring the link between domestic violence and animal abuse. Aggress. Violent Behav. 2017, 34, 273-281. [CrossRef]

34. Bennett, E.R. Logic and Limits of Animal Liberation. In Advances in Animal Welfare Science; Springer: Berlin/Heidelberg, Germany, 1985; pp. 89-99.

35. Damasio, A. Looking for Spinoza: Joy, Sorrow, and the Feeling Brain; Harcourt: Boston, MA, USA, 2003.

36. Tomasello, M. A Natural History of Human Morality; Harvard University Press: Harvard, UK, 2016.

37. Aerni, P.; Grün, K.-J. Moral und Angst; Vandenhoeck und Ruprecht: Göttingen, Germany, 2011.

38. Spinoza, B. Ethik in Geometrischer Ordnung Dargestellt (First Published in 1670); Felix Meiner Verlag: Hamburg, Germany, 2011.

39. Grey, J. Use them at your pleasure: Spinoza on animal ethics. Hist. Philos. Q. 2013, 30, 367-388.

40. Dhont, K.; Hodson, K.; Leite, A.C.; Salmen, A. The psychology of speciesism. In Why We Love and Exploit Animals: Bridging Insights from Academia and Advocacy; Dhont, K., Hodson, G., Eds.; Routledge: London, UK, 2019; pp. $29-49$.

41. Caviola, L.; Everett, J.A.C.; Faber, N.S. The moral standing of animals: Towards a psychology of speciesism. J. Personal. Soc. Psychol. 2019, 116, 1011-1029. [CrossRef] [PubMed]

42. Oberg, A. All too human? Speciesism, racism, and sexism. Think 2016, 15, 39. [CrossRef]

43. Weitzenfeld, A.; Joy, M. An overview of anthropocentrism, humanism, and speciesism in critical animal theory. Counterpoints 2014, 448, 3-27.

44. Scotton, G. Metaphors and maladies: Against psychologizing speciesism. In Animaladies: Gender, Animals, and Madness; Adams, C.J., Ed.; Bloomsbury Publishing: London, UK, 2018; pp. 101-116.

45. Inglehart, R.; Welzel, C. Modernization, Cultural Change, and Democracy: THE human Development Sequence; Cambridge University Press: Cambridge, UK, 2005.

46. Inglehart, R. Modernization, Existential Security and Cultural Change: Reshaping Human Motivations and Society. In Handbook of Advances in Culture and Psychology; Hong, Y., Gelfand, M.J., Chiu, C., Eds.; Oxford University Press: Oxford, UK, 2018 ; Volume 7.

47. Campbell, B.; Manning, J. The Rise of Victimhood Culture: Microaggressions, Safe. Spaces, and the New Culture Wars; Springer: Berlin/Heidelberg, Germany, 2018.

48. Francione, G.L. Some brief comments on animal rights. Anim. Front. Rev. Mag. Anim. Agric. 2020, 10, 29-33. [CrossRef]

49. Pulina, G. Ethical meat: Respect for farm animals. Anim. Front. 2020, 10, 34-38. [CrossRef]

50. Righetti, N.; Bertuzzi, N. Digital Animal Advocacy: A Study on Facebook Communication Styles of Italian Animal Rights Organizations and their Followers' Reactions. Mediascapes J. 2020, 16, 128-150.

51. Gehlen, A. Moral und Hypermoral; Athenäum Verlag: Frankfurt, Germany, 1970.

52. Haidt, J. The Righteous Mind: Why Good People are Divided by Politics and Religion; Vintage: New York, NY, USA, 2012.

53. Damasio, A. Neuroscience and ethics: Intersections. Am. J. Bioeth. 2007, 7, 3-7. [CrossRef] [PubMed]

54. Corning, P. The Fair Society: The Science of Human Nature and the Pursuit of Social Justice; University of Chicago Press: Chicago, IL, USA, 2011. 
55. Beller, B. Anthropologie und Ethik bei Arnold Gehlen. Ph.D. Thesis, Ludwig Maximilian Universität München, München, Germany, 2010.

56. Mattingly, C.; Throop, J. The anthropology of ethics and morality. Annu. Rev. Anthropol. 2018, 47, 475-492. [CrossRef]

57. Zeder, M.; Smith, B. A conversation on agriculture: Talking past each other in a crowded room. Curr Anthr. 2009, 50, 681-691. [CrossRef]

58. Zeder, M.A. The domestication of animals. J. Anthropol. Res. 2012, 68, 161-190. [CrossRef]

59. Zeder, M.A. Core questions in domestication research. Proc. Natl. Acad. Sci. USA 2015, 112, 3191-3198. [CrossRef] [PubMed]

60. Crutzen, P.J.; Stoermer, E.F. The Anthropocene. Igbp Newsl. 2000, 41, 12.

61. Zalasiewicz, J.; Williams, M.; Smith, A.; Barry, T.; Coe, A.; Brown, P.; Brenchley, P.; Cantrill, D.; Gale, A.; Gibbard, P.; et al. Are we now living in the Anthropocene? Gsa Today 2008, 18, 4-8. [CrossRef]

62. Steffen, W.; Broadgate, W.; Deutsch, L.; Gaffney, O.; Ludwig, C. The trajectory of the Anthropocene: The great acceleration. Anthr. Rev. 2015, 2, 81-98. [CrossRef]

63. Ruddiman, W.F.; Thomson, J.S. The case for human causes of increased atmospheric CH4 over the last 5000 years. Quat. Sci. Rev. 2001, 20, 1769-1777. [CrossRef]

64. Ruddiman, W. Plows, Plagues \& Petroleum-How Humans Took Control. of Climate; Princeton University Press: Princeton, NJ, USA; Oxford, UK, 2005.

65. Ruddiman, W. The Anthropocene. Annu. Rev. Earth Planet. Sci. 2013, 41, 45-68. [CrossRef]

66. Ruddiman, W.F. Defining the epoch we live in. Science 2015, 348, 38-39. [CrossRef]

67. Smith, B.D.; Zeder, M.A. The onset of the Anthropocene. Anthropocene 2013, 4, 8-13. [CrossRef]

68. Bar-Yosef, O.; Price, T.D. The origins of agriculture: New data, newideas. Current Anthropology 2011, 52, S163-S174.

69. Zalasiewicz, J.; Waters, C.N.; Summerhayes, C.P.; Wolfe, A.P.; Barnosky, A.D.; Cearreta, A.; Crutzen, P.; Ellis, E.; Fairchild, I.J.; Gałuszka, A.; et al. The Working Group on the Anthropocene: Summary of evidence and interim recommendations. Anthropocene 2017, 19, 55-60. [CrossRef]

70. Harari, Y. Homo Sapiens: A Brief. History of Mankind; Random House: New York, NY, USA, 2015.

71. Kunnas, J. Storytelling: From the early Anthropocene to the good or the bad Anthropocene. Anthr. Rev. 2017, 4, 136-150. [CrossRef]

72. Zeder, M.A. Domestication and early agriculture in the Mediterranean Basin: Origins, diffusion, and impact. Proc. Natl. Acad. Sci. USA 2008, 105, 11597-11604. [CrossRef]

73. Fuller, D.Q.; Willcox, G.; Allaby, R.G. Cultivation and domestication had multiple origins: Arguments against the core area hypothesis for the origins of agriculture in the Near East. World Archaeol. 2011, 43, 628-652. [CrossRef]

74. Cohen, M. The Food Crisis in Prehistory: Overpopulation and the Origins of Agriculture; Yale University Press: New Haven, CT, USA, 1977.

75. Gremillion, K.J.; Barton, L.; Piperno, D.R. Particularism and the retreat from theory in the archaeology of agricultural origins. Proc. Natl. Acad. Sci. USA 2014, 111, 6171-6177. [CrossRef]

76. Stiner, M.C. Thirty years on the "broad spectrum revolution" and paleolithic demography. Proc. Natl. Acad. Sci. USA 2001, 98, 6993-6996. [CrossRef]

77. Winterhalder, B.; Kennett, D.J. Behavioral ecology and the transition from hunting and gathering to agriculture. In Behavioral Ecology and the Transition to Agriculture; Kennett, D.J., Winterhalder, B., Eds.; University of California Press: Berkeley, CA, USA, 2006; pp. 1-21.

78. Bettinger, R. Agriculture, archaeology, and human behavioral ecology. In Behavioral Ecology and the Transition to Agriculture; Kennett, D.J., Winterhalder, B., Eds.; University of California Press: Berkeley, CA, USA, 2006; pp. 304-322.

79. Cauvin, J. The Birth of the Gods and the Origins of Agriculture; Cambridge University Press: Cambridge, UK, 2000.

80. Hayden, B. Were luxury foods the first domesticates? Ethnoarchaeological perspectives from Southeast Asia. J. World Prehistory Camb. 2003, 34, 458-469. [CrossRef]

81. Rowley-Conwy, P. North of the frontier: Early domestic animals in northern Europe. In The Origins and Spread of Domestic Animals in Southwest Asia and Europe; Colledge, S., Conolly, J., Dobney, K., Manning, M., Shennan, S., Eds.; Left Coast: Walnut Creek, CA, USA, 2013; pp. 283-312.

82. Price, M.; Hongo, H. The archaeology of pig domestication in Eurasia. J. Archaeol. Res. 2019, 28, 557-615. [CrossRef]

83. Lander, B.; Schneider, M.; Brunson, K. A History of Pigs in China: From Curious Omnivores to Industrial Pork. J. Asian Stud. 2020, 79, 865-889. [CrossRef]

84. Mueller, U.G.; Ishak, H.D.; Bruschi, S.M.; Smith, C.C.; Herman, J.J.; Solomon, S.E.; Mikheyev, A.S.; Rabeling, C.; Scott, J.J.; Cooper, M.; et al. Biogeography of mutualistic fungi cultivated by leafcutter ants. Mol. Ecol. 2017, 26, 6921-6937. [CrossRef] [PubMed]

85. Day, R.L.; Laland, K.N.; Odling-Smee, F.J. Rethinking Adaptation: The Niche-Construction Perspective. Perspect. Biol. Med. 2003, 46, 80-95. [CrossRef] [PubMed]

86. Odling-Smee, F.J.; Laland, K.N.; Feldman, M.W. Niche Construction: The Neglected Process in Evolution (MPB-37); Princeton University Press: Princeton, NJ, USA, 2013.

87. Akhtar, A. Our Symphony with Animals: On Health, Empathy, and Our Shared Destinies; Simon and Schuster: New York, NY, USA, 2019. 
88. Klingbacher, B. Die Geschichte von Saueli und Millionen Anderen Schweinen, Denen wir erst vor dem Kühlregal Begegnen. NZZ. 19 December 2020. Available online: https:/ / www.nzz.ch/gesellschaft/vom-schwein-zum-rollschinkli-ld.1592439?reduced=true (accessed on 22 January 2021).

89. Lewontin, R.C. Gene, organism and environment. In Evolution from Molecules to Men; Cambridge University: Cambridge, UK, 1983; pp. 273-285.

90. Smith, B.D. A comparison of niche construction theory and diet breadth models as explanatory frameworks for the initial domestication of plants and animals. J. Archaeol. Res. 2015, 23, 215-262. [CrossRef]

91. Kendal, J.; Tehrani, J.J.; Odling-Smee, J. Human niche construction in interdisciplinary focus. Phil. Trans. R. Soc. B 2011, 366, 785-792. [CrossRef] [PubMed]

92. Oldenquist, A. The origins of morality: An essay in philosophical anthropology. Soc. Philos. Policy 1990, 8, 121-140. [CrossRef]

93. Henrich, J.; Henrich, N. Why Humans Cooperate: A Cultural and Evolutionary Explanation; Oxford University Press: Oxford, UK, 2007.

94. Naderi, S.; Rezaei, H.R.; Pompanon, F.; Blum, M.G.; Negrini, R.; Naghash, H.R. The goat domestication process inferred from large-scale mitochondrial DNA analysis of wild and domestic individuals. Proc. Natl. Acad. Sci. USA 2008, 105, 17659-17664. [CrossRef]

95. Koknaroglu, H.; Akunal, T. Animal welfare: An animal science approach. Meat Sci. 2013, 95, 821-827. [CrossRef]

96. Mouzo, D.; Rodríguez-Vázquez, R.; Lorenzo, J.M.; Franco, D.; Zapata, C.; López-Pedrouso, M. Proteomic application in predicting food quality relating to animal welfare. A review. Trends Food Sci. Technol. 2020, 99, 520-530. [CrossRef]

97. Phillips, C.J.C.; Izmirli, S.; Aldavood, S.J.; Alonso, M.; Choe, B.I.; Hanlon, A. Students' attitudes to animal welfare and rights in Europe and Asia. Anim. Welf. Ufaw J. 2012, 21, 87. [CrossRef]

98. Offor, I. Second wave animal ethics and (global) animal law: A view from the margins. J. Hum. Rights Environ. 2020, 11, 268-296. [CrossRef]

99. Freeman, C.P. The Human Animal Earthling Identity: Shared Values Unifying Human Rights, Animal Rights, and Environmental Movements; University of Georgia Press: Athens, GA, USA, 2020.

100. Aerni, P. (Forthcoming) 'Business as part of the solution: SDG 8 challenges textbook views on sustainable development'. In MPDI Book Series on Transitioning toward Sustainability; Aerni, P., Schluep, I., Stavridou, M., Eds.; MDPI: Basel, Switzerland; Available online: https: / /www.mdpi.com/books/pdfview/edition/1227 (accessed on 5 March 2021).

101. Juma, C. Development: Starved for solutions. Nature 2013, 500, 148-149. [CrossRef]

102. Juma, C. Innovation and its Enemies: Why People Resist. New Technologies; Oxford University Press: Oxford, UK, 2016.

103. Puska, P.; Kurki, S.; Lähdesmäki, M.; Siltaoja, M.; Luomala, H. Sweet taste of prosocial status signaling: When eating organic foods makes you happy and hopeful. Appetite 2018, 121, 348-359. [CrossRef] [PubMed]

104. Griskevicius, V.; Tybur, J.M.; Van den Bergh, B. Going green to be seen: Status, reputation, and conspicuous conservation. J. Personal. Soc. Psychol. 2010, 98, 392. [CrossRef]

105. Kafashan, S.; Sparks, A.; Griskevicius, V.; Barclay, P. Prosocial behavior and social status. In The Psychology of Social Status; Cheng, J.T., Tracy, J.L., Eds.; Springer: Berlin/Heidelberg, Germany, 2014; pp. 139-158.

106. Editorial. The cooperative human. Nat. Hum. Behav 2018, 2, 427-428. [CrossRef] 